\title{
All-trans Retinoic Acid Converts E2F into a Transcriptional Suppressor and Inhibits the Growth of Normal Human Bronchial Epithelial Cells Through a Retinoic Acid Receptor-dependent Signaling Pathway
}

\author{
Ho-Young Lee, ${ }^{\star}$ David F. Dohi, ${ }^{*}$ Yeul-Hong Kim, ${ }^{\star}$ Garrett L. Walsh, ${ }^{\ddagger}$ Ugo Consoli, ${ }^{\S}$ Michael Andreeff, ${ }^{\S}$ Marcia I. Dawson, \\ Waun Ki Hong, ${ }^{\star}$ and Jonathan M. Kurie* \\ $*$ Department of Thoracic/Head and Neck Medical Oncology, ${ }^{\ddagger}$ Department of Thoracic and Cardiovascular Surgery, and ${ }^{\S}$ Department of \\ Hematology, The University of Texas M.D. Anderson Cancer Center, Houston, Texas 77030; "Laboratory of Bio-Organic Chemistry, SRI \\ International, Palo Alto, California 94025
}

\begin{abstract}
Retinoids, including retinol and retinoic acid derivatives, maintain the normal growth and differentiation of human bronchial epithelial (HBE) cells and are under investigation as agents for lung cancer prevention. In this study, we examined the biologic effects of retinoids on normal HBE cells and the molecular mechanisms of retinoid actions. At a dose of $10^{-6} \mathrm{M}$, all-trans retinoic acid (t-RA) suppressed the proliferation of normal HBE cells, which accumulated in the $\mathrm{G}_{0}$ phase. No evidence of programmed cell death was observed. The class of retinoid nuclear receptor that mediated the growth arrest was explored. Normal HBE cell growth was suppressed by a retinoid that selectively activates retinoic acid receptors but not by one that activates retinoid $X$ receptors. The E2F transcription factor has demonstrated a role in $G_{0}$ entry through transcriptional suppression of genes that induce cell cycle progression. To investigate the role of E2F in retinoid signaling, transient transfection assays were performed using reporter plasmids containing E2F-binding sites. Findings from these experiments suggested that t-RA treatment converted E2F into a transcriptional suppressor. Supporting this possibility, t-RA inhibited the expression of the E2F target genes B-myb, cyclin A, and cyclin $E$. Further, t-RA increased the levels of nuclear E2F-4, p107, and p130 and enhanced the binding of E2F-4 to $\mathrm{p} 107$, which have been associated with the conversion of E2F into a transcriptional suppressor in other cells. These findings point to retinoic acid receptor- and E2F-dependent pathways as potential mediators of retinoid-induced growth arrest in normal HBE cells and have implications for the use of retinoids in clinical trials on the prevention of lung cancer. (J. Clin. Invest. 1998. 101:1012-1019.) Key words: p107 $\bullet$ p130 retinoid nuclear receptor
\end{abstract}

Address correspondence to Jonathan M. Kurie, M.D., Box 80, M.D. Anderson Cancer Center, 1515 Holcombe Blvd., Houston, TX 77030. Phone: 713-792-6363; FAX: 713-796-8655; E-mail: jmkurie@mdacc. tmc.edu

Received for publication 29 July 1997 and accepted in revised form 18 December 1997.

J. Clin. Invest.

(C) The American Society for Clinical Investigation, Inc. 0021-9738/98/03/1012/08 \$2.00

Volume 101, Number 5, March 1998, 1012-1019

http://www.jci.org

\section{Introduction}

Retinoid treatment induces a variety of changes in the growth and differentiation of tracheobronchial epithelial cells. In rodents deprived of vitamin $\mathrm{A}$, the tracheobronchial epithelium develops squamous changes, and normal epithelial differentiation is restored by vitamin A supplementation (1,2). In tissue culture, human bronchial epithelial $(\mathrm{HBE})^{1}$ cells undergo squamous differentiation in response to a variety of conditions, and treatment with all-trans retinoic acid (t-RA) inhibits this process (3-7). In collagen gels, normal HBE cells undergo mucous differentiation in response to t-RA treatment (8). Grown in monolayer cultures, retinol-treated HBE cells undergo growth arrest with no evidence of morphologic differentiation (9). These findings demonstrate the importance of retinoids in the maintenance of normal tracheobronchial epithelial growth and differentiation and provide a rationale for the use of retinoids in the prevention of lung cancer. Supporting this hypothesis, retinoids have demonstrated activity in an initial trial on lung cancer prevention (10) and are the subject of ongoing trials in the United States and Europe.

Retinoid actions are mediated through nuclear receptors, including the retinoic acid receptor (RAR) and retinoid X receptor (RXR) families (11-16). These receptors function as RXR homodimers and as heterodimers of RXR with RAR, vitamin $\mathrm{D}$ receptor, thyroid receptor, and certain orphan receptors (17-27). Retinoid receptor transcriptional activity is regulated by ligand binding. Of the known natural retinoids, t-RA activates RARs, and 9-cis retinoic acid activates both RARs and RXRs $(28,29)$. Intracellularly, t-RA can undergo isomerization to 9-cis retinoic acid (30), activating both RAR- and RXR-dependent signaling pathways. Unlike these natural retinoids, synthetic retinoids have been developed that are conformationally-restricted to selectively activate RARs or RXRs $(31,32)$. Treatment with these receptor-selective retinoids has demonstrated that RAR and RXR signaling pathways have distinct roles in the growth and differentiation of embryonal carcinoma cells, ectocervical epithelial cells, and HL-60 leukemia cells (33-35).

Retinoid receptors activate the expression of target genes directly by binding to gene promoter regions and indirectly by binding to other transcription factors. Through these mechanisms, activation of RAR-dependent signaling pathways inhib-

1. Abbreviations used in this paper: BrdU, bromodeoxyuridine; $\mathrm{HBE}$, human bronchial epithelial; RAR, retinoic acid receptor; $\mathrm{RB}$, retinoblastoma; RXR, retinoid X receptor; SR11235, 2-(4-Carboxyphenyl)2-(5,6,7,8-tetrahydro-5,5,8,8-tetramethyl-2-naphthalenyl)-1,3-oxathiolane; t-RA, all-trans retinoic acid; TTNPB, E-4-[2-(5,5,8,8-tetramethyl5,6,7,8-tetrahydro-2-naphthalenyl)-1-propenyl] benzoic acid. 
its the transcriptional activity of the AP-1 transcription factor and increases the expression of transglutaminase type II, transforming growth factor- $\beta$ family members, and insulin-like growth factor binding proteins, which have demonstrated growth inhibitory effects in specific cell types (36-40). The mechanisms by which these retinoid signaling pathways control cell growth have not been defined. Progress in this area will require insight into the effects of retinoids on the passage of cells through specific cell cycle checkpoints. An essential component of the cell cycle is the E2F transcription factor family. E2F can function as a transcriptional activator or suppressor (41-43). E2F is converted into a transcriptional suppressor by its association with one of the retinoblastoma (RB) family members pRB, p130, or p107 (41-43). Its dual function is at the basis of the current model describing E2F's role in the cell cycle. Through transcriptional activation or suppression of key growth regulatory genes, E2F can either promote or inhibit the passage of cells through specific cell cycle checkpoints. These checkpoints are regulated by different E2F family members: $\mathrm{E} 2 \mathrm{~F}-1$ controls entry into $\mathrm{S}$ phase, and $\mathrm{E} 2 \mathrm{~F}-4$ regulates entry into $\mathrm{G}_{0} / \mathrm{G}_{1}(41-43)$.

In this study, we investigated the effect of t-RA on the growth of normal HBE cells and the retinoid signaling pathways that mediate t-RA actions. t-RA treatment inhibited the growth of normal HBE cells, which accumulated in the $G_{0}$ phase with no evidence of programmed cell death. The reduction in cell number caused by t-RA was reproduced by treatment with a RAR-selective retinoid. Transient transfection and co-immunoprecipitation studies suggested that t-RA converted E2F into a transcriptional suppressor, potentially through an enhanced association of E2F-4 with p107. These findings support further investigations into the role of RARand E2F-dependent pathways as mediators of retinoid-induced growth arrest in normal HBE cells.

\section{Methods}

Cell culture and growth conditions. Normal HBE cells were grown from bronchial mucosal biopsy samples resected from fresh surgical specimens as previously described (44). Briefly, the mucosal layer was sterilely stripped from bronchial specimens, cut into small pieces, and placed on a plastic tissue culture plate containing a thin layer of medium. When normal HBE cells had grown from these tissues into a $60 \%$ confluent monolayer population, they were expanded for use in experiments. Normal HBE cells were grown on standard plasticware (Falcon Labware, Becton Dickinson and Co., Franklin Lakes, NJ) in Keratinocyte Serum-Free Medium (GIBCO BRL, Gaithersburg, $\mathrm{MD})$ containing epidermal growth factor and bovine pituitary extract at $37^{\circ} \mathrm{C}$ with a $\mathrm{pCO}_{2}$ of $5 \%$. When treated with retinoids, normal $\mathrm{HBE}$ cells were grown in the absence of epidermal growth factor. t-RA was purchased from Sigma Chemical Co. (St. Louis, MO). E-4-[2-(5,5,8,8tetra-methyl-5,6,7,8-tetrahydro-2-naphthalenyl)-1-propenyl] benzoic acid (TTNPB) was obtained from Dr. Richard Heyman (Ligand Pharmaceuticals, San Diego, CA) (45), and 2-(4-Carboxyphenyl)-2(5,6,7,8-tetrahydro-5,5,8,8-tetramethyl-2-naphthalenyl)-1,3-oxathiolane (SR11235) was synthesized as previously described (46).

Assays for induction of apoptosis. After treatment with t-RA $\left(10^{-6} \mathrm{M}\right)$ or medium alone, normal HBE cells were examined by in situ end labeling to quantitate the number of apoptotic cells. A slightly modified version of the method for in situ end labeling of DNA strand breaks (47) was used. Briefly, cells were trypsinized, and $10^{6}$ cells were removed, washed twice in PBS, and resuspended in $5 \mathrm{ml}$ of $70 \%$ cold $\left(-20^{\circ} \mathrm{C}\right)$ ethanol. After rehydration in PBS, cells were resuspended for $1 \mathrm{~h}$ at $37^{\circ} \mathrm{C}$ in $50 \mu \mathrm{l}$ of a cacodylate buffer con- taining $0.2 \mathrm{M}$ potassium cacodylate, $2.5 \mathrm{mM}$ Tris- $\mathrm{HCl}$ ( $\mathrm{pH}$ 6.6), 2.5 $\mathrm{mM} \mathrm{CoCl}, 0.25 \mathrm{mg} / \mathrm{ml} \mathrm{BSA}, 7 \mathrm{U}$ terminal deoxynucleotidyl transferase, and $0.5 \mathrm{nmol}$ biotinylated dUTP (Boehringer Mannheim Biochemicals, Indianapolis, IN). After incubation, cells were rinsed twice in cold PBS and resuspended in $100 \mu \mathrm{l}$ of a solution containing $4 \times$ concentrated saline-sodium citrate buffer (Sigma Chemical Co.), 2.5 $\mu \mathrm{g} / \mathrm{ml}$ fluoresceinated avidin (Becton Dickinson), $0.1 \%$ Triton X-100, and $1 \%(\mathrm{wt} / \mathrm{vol})$ nonfat dry milk. The cells were incubated in this solution for $30 \mathrm{~min}$ at room temperature in the dark and then rinsed in PBS containing $0.1 \%$ Triton X-100. As a control, each sample was treated according to the same procedure except the terminal deoxynucleotidyl transferase enzyme was omitted from the incubation buffer. Cells were then resuspended in $500 \mu \mathrm{l}$ of PBS and analyzed on a FACScan ${ }^{\circledR}$ flow cytometer (Becton Dickinson Immunocytometry Systems, San Jose, CA). The data from $10^{4}$ cells were collected, stored, and analyzed by using Lysys II software.

DNA fragmentation associated with apoptosis was determined on DNA isolated from normal HBE cells after 3 or $5 \mathrm{~d}$ of treatment with $10^{-6} \mathrm{M}$ t-RA or medium alone. DNA was isolated from $10^{6}$ cells by lysis in $10 \mathrm{mM}$ Tris- $\mathrm{HCl}$ (pH 7.4) containing $20 \mathrm{mM}$ EDTA and $0.1 \%$ Triton X-100 followed by treatment with $100 \mathrm{mg} / \mathrm{ml}$ proteinase $\mathrm{K}$ (Sigma Chemical Co.) for $16 \mathrm{~h}$ at $55^{\circ} \mathrm{C}$. The partially deproteinated extract was centrifuged at $30,000 \mathrm{~g}$ for $45 \mathrm{~min}$ at $4^{\circ} \mathrm{C}$ to separate unfragmented DNA from small, nucleosomal fragments. The resulting pellet was discarded, and the supernatant was treated with ribonuclease A (Sigma Chemical Co.) for $4 \mathrm{~h}$ at $37^{\circ} \mathrm{C}$. The supernatant was electrophoresed on a $2.0 \%$ agarose gel containing ethidium bromide, visualized under ultraviolet light, and photographed.

Bromodeoxyuridine incorporation. After $5 \mathrm{~d}$ of treatment with t-RA $\left(10^{-6} \mathrm{M}\right)$ or medium alone, normal HBE cells were treated with $10 \mu \mathrm{g} / \mathrm{ml}$ bromodeoxyuridine (BrdU; Sigma Chemical Co.) for $2 \mathrm{~h}$. The cells were trypsinized, cytospun onto slides, and fixed as described (48). The cells were incubated with a monoclonal antibody to BrdU (mAbBR3; Caltag Laboratories, South San Francisco, CA) and detected with the Vectastain ABC Elite kit (Vector Laboratories, Inc., Burlingame, CA) and diaminobenzidine. The cells were then counter-stained with Giemsa. The percentage of cells incorporating BrdU was determined among 500 randomly counted cells.

Acridine orange staining. Acridine orange staining permits quantitation of, and distinction between, cells in $\mathrm{G}_{0}$ and $\mathrm{G}_{1}$. After $5 \mathrm{~d}$ of treatment with t-RA $\left(10^{-6} \mathrm{M}\right)$ or medium alone, normal HBE cells were stained with acridine orange and analyzed by flow cytometry. Briefly, $10^{6}$ cells were fixed in $1 \%$ paraformaldehyde, treated on ice with a Triton $\mathrm{X}$ buffer, and stained with acridine orange solution as described (49). A FACScan ${ }^{\circledR}$ flow cytometer was used, and data were analyzed with Lysis II software.

Reporter plasmids. pGL2-AN is a reporter plasmid containing a 275-bp fragment of the E2F-1 gene promoter (Asp 718-NcoI) cloned into pGL2-basic (pGL2-AN). pGL2-AN $\Delta \mathrm{A}+\mathrm{B}$ contains the same fragment of the E2F-1 promoter with mutations in the two known E2F binding sites that abolish binding of E2F to this promoter region (50). These were provided by Dr. William G. Kaelin (Dana Farber Cancer Institute, Boston, MA).

Transient transfection assays. E2F transcriptional activity was determined in normal HBE cells at $24 \mathrm{~h}$ intervals (0-24, 24-48, and 48$72 \mathrm{~h}$, respectively) during $5 \mathrm{~d}$ of $10^{-6} \mathrm{M}$ t-RA treatment. Normal HBE cells were seeded on six-well plates at a density of 104 cells per well. The cells were treated with $10^{-6} \mathrm{M}$ t-RA beginning 72,96 , and $120 \mathrm{~h}$ from the time of seeding. At $120 \mathrm{~h}$ from the time of seeding, the cells were transiently transfected by lipofectamine-mediated DNA transfer with $2 \mu \mathrm{g}$ of pGL2-AN or pGL2-AN $\Delta \mathrm{A}+\mathrm{B}$. After $24 \mathrm{~h}$, the cells were subjected to luciferase assays as previously described (44). The results represent the means and SD of five identical wells.

Sulforhodamine B colorimetric assay. Normal HBE cells were seeded at a density of $1.3 \times 10^{3}$ cells per well in a 24-well plate and grown for $5 \mathrm{~d}$ in the presence of t-RA, TTNPB, or SR11235 at different dosages or in media alone. The media was then removed, and cells were fixed with $200 \mathrm{ml}$ of $10 \%$ trichloroacetic acid per well for 
$1 \mathrm{~h}$ at $4^{\circ} \mathrm{C}$. After rinsing the plates five times in deionized water, the cells were stained with $0.4 \%$ (wt/vol) Sulforhodamine B in $1 \%$ acetic acid for $10 \mathrm{~min}$ at room temperature. The plates were then rinsed five times with $1 \%$ acetic acid and air dried. Bound dye was solubilized with $200 \mu \mathrm{l}$ of $10 \mathrm{mM}$ unbuffered Tris base, and absorption was determined at $490 \mathrm{~nm}$ in a Dynatech MR5000 Elisa Plate Reader (Dynex Technologies, Inc., Chantilly, VA). The results represent the means and SD of five identical wells.

Western analysis. Normal HBE cells were seeded at a density of $10^{5}$ cells per $10 \mathrm{~cm}$ plate and treated with $10^{-6} \mathrm{M}$ t-RA or media alone. Nuclear and cytoplasmic fractions were isolated as previously described (40). Whole cell, nuclear, and cytoplasmic lysates were prepared in MEGA-RIPA buffer (50 mM Tris-HCl, pH 8.0; $100 \mathrm{mM}$ $\mathrm{NaF} ; 0.5 \%$ NP-40; $0.5 \%$ deoxycholate; $200 \mathrm{mM} \mathrm{NaCl} ; 20 \mathrm{mM} \beta$-glycerophosphate; $10 \mathrm{mM}$ benzamidine; $5 \mathrm{mM}$ EDTA; $0.6 \mathrm{mM}$ phenylmethylsulfonyl fluoride; $10 \mathrm{mg} / \mathrm{ml}$ leupeptin; $10 \mathrm{mg} / \mathrm{ml}$ aprotinin; 200 $\left.\mathrm{mM} \mathrm{Na}_{3} \mathrm{VO}_{4}\right)$. Protein lysate $(50 \mu \mathrm{g})$ was separated by electrophoresis on a SDS-7.5\% polyacrylamide gel, transferred onto a BA-S-83reinforced nitrocellulose membrane (Schleicher \& Schuell, Inc., Keene, $\mathrm{NH}$ ), and immunoblotted overnight at $4{ }^{\circ} \mathrm{C}$ with a primary monoclonal antibody to E2F-4, pRB, p107, or p130 (Santa Cruz Biotechnology, Inc., Santa Cruz, CA). Binding was detected by using the ECL kit (Amersham Corp., Arlington Heights, IL) according to the manufacturer's directions. Co-immunoprecipitation was performed by incubation of $300 \mu \mathrm{g}$ of whole cell lysate with E2F-4 monoclonal antibody for $3 \mathrm{~h}$ at room temperature, followed by the addition of Sepharose beads, incubation overnight at $4^{\circ} \mathrm{C}$, electrophoresis of the immunoprecipitated sample on a SDS-7.5\% polyacrylamide gel, Western blotting with antibodies to p107 or p130, and detection using the ECL kit.

Band shift assay. Nuclear extracts were prepared as previously described (40). Nuclear extracts $(10 \mu \mathrm{g})$ were preincubated with $2 \mathrm{mg}$ of poly (dI-dC) for $15 \mathrm{~min}$ at $4^{\circ} \mathrm{C}$ and then incubated with labeled oligomer DNA $(6,000 \mathrm{cpm})$ for $15 \mathrm{~min}$ at $4^{\circ} \mathrm{C}$ in the presence of $10 \mathrm{mM}$ Tris- $\mathrm{HCl}(\mathrm{pH} 7.5), 10 \mathrm{mM} \mathrm{KCl}, 1 \mathrm{mM}$ EDTA, $20 \%$ glycerol, $1 \mathrm{mM}$ dithiothreitol, and $5 \mathrm{mM} \mathrm{MgCl}$. The oligomers were commercially prepared (Operon Biotechnologies, Inc., Alameda, CA) based on DNA sequences within the E2F-1 gene promoter that include the two E2F-binding sites (E2FA and B) (50). Oligomer sequences were as follows: (consensus-binding sequences are in bold): E2FA: 5'-CTAGAGCTCTTTCGCGGCAAAAAGGAG-3', and 3'-GATCTCGAGAAAGCGCCGTTTTTCCTC-5'; E2FB: 5'-CTAGAGGATTTGGCCGTAAAAGTGG- $3^{\prime}$, and $3^{\prime}$-GATCTCCTAAACCGGCATTTTCACC-5'. Oligomers were end-labeled with $\left[\chi^{-32} \mathrm{P}\right] \mathrm{ATP}(4,000 \mathrm{Ci} /$ mol) using $\mathrm{T}_{4}$ polynucleotide kinase (Boehringer Mannheim Biochemicals) and purified by ethanol precipitation. For competition experiments, excess nonradioactive oligomers (consensus or unrelated) were added before the addition of radioactive oligomers. The reaction mixture was subjected to electrophoresis on a $5 \%$ nondenaturing polyacrylamide gel (75:1 acrylamide:bis-acrylamide). The gel was then dried and autoradiographed using an amplifying screen at $-80^{\circ} \mathrm{C}$. Super-shift analysis was performed with monoclonal antibodies to RAR- $\alpha$ or RXR- $\alpha$ (51), which were a generous gift from Dr. Elizabeth Allegretto (Ligand Pharmaceuticals). As a positive control for this experiment, super-shift analysis was performed on these lysates in the presence of the antibodies using oligonucleotides specific for retinoid nuclear receptor response elements (AGGTCA repeats separated by five nucleotides).

Northern analysis. Normal HBE cells were seeded at a density of $10^{5}$ cells per $10-\mathrm{cm}$ plate and treated for $3 \mathrm{~d}$ with $10^{-6} \mathrm{M} \mathrm{t}$-RA or medium alone. Total cellular RNA was prepared as previously described (44). RNA was subjected to electrophoresis ( $30 \mu \mathrm{g}$ per lane) on a $1 \%$ agarose gel containing $2 \%$ formaldehyde, transferred to a nylon membrane (Duralon UV; Stratagene, Inc., La Jolla, CA), hybridized to an $\left[\alpha-{ }^{32} \mathrm{P}\right] \mathrm{dCTP}-$ labeled cDNA probe, washed in high stringency conditions, and autoradiographed for 24-48 h. The B-myb, cyclin A, and cyclin E cDNA probes used in this study were previously described (52).

\section{Results}

Effects of t-RA on normal HBE cell growth. Normal HBE cells were treated with t-RA at different dosages or with medium alone, and cells were counted at 3 and $5 \mathrm{~d}$. At $5 \mathrm{~d}, 10^{-8} \mathrm{M}$ and $10^{-6} \mathrm{M}$ t-RA decreased the number of normal HBE cells to 47 and $20 \%$, respectively, of controls (Fig. $1 A$ ), demonstrating dose-dependent, growth-inhibitory effects of t-RA on normal HBE cells.

To further investigate the growth inhibition induced by t-RA, normal HBE cells were treated with $10^{-6} \mathrm{M} \mathrm{t-RA}$ or with media alone for $5 \mathrm{~d}$, and the proportion of cells actively proliferating was examined by in situ analysis of BrdU incorporation (Fig. $1 B$ ) and by flow cytometric analysis of cells stained with acridine orange (Fig. $1 C$ ). Each experiment required the use of a separate bronchial biopsy sample to obtain adequate numbers of cells. In untreated cells obtained from three separate biopsy samples, the percentages that incorporated BrdU were 17,18 , and $28 \%$, respectively, reflecting the heterogeneity of primary HBE cells from different biopsies. BrdU incorporation in t-RA-treated cells from the three biopsies was 3,6, and $18 \%$, respectively, demonstrating that t-RA inhibited BrdU incorporation 85, 67, and 34\%, respectively, in these three experiments. In cells from a fourth biopsy, flow cytometric analysis was performed after acridine orange staining, which permits quantitation of, and distinction between, cells in $\mathrm{G}_{0}$ and $\mathrm{G}_{1}$. This revealed that the cell populations in $\mathrm{S}$ phase in control and t-RA-treated cells were 37 and $23 \%$, respectively, demonstrating that $\mathrm{t}-\mathrm{RA}$ reduced the $\mathrm{S}$ phase population by $38 \%$, and t-RA treatment increased the percentage of cells in the $\mathrm{G}_{0}$ phase from 6 to $38 \%$. These findings demonstrate that t-RA induced a proliferative arrest, with an accumulation of cells in the $\mathrm{G}_{0}$ phase.

We investigated whether programmed cell death contributed to the reduction in cell number induced by t-RA treatment. Normal HBE cells were treated with $10^{-6} \mathrm{M}$ t-RA or medium alone for 3 or $5 \mathrm{~d}$ and trypsinized. Evidence of DNA fragmentation was examined by flow cytometric analysis of cells after end labeling using biotinylated dUTP. Incorporation of dUTP was not detectably enhanced by $10^{-6} \mathrm{M}$ t-RA (data not shown). HL-60 cells, which undergo apoptosis when treated with ARA-C, served as a positive control in this experiment. Evidence for DNA fragmentation was further examined by performing agarose gel electrophoresis to resolve oligonucleosomal DNA fragments. DNA was extracted from normal HBE cells after 3 or $5 \mathrm{~d}$ of treatment with $10^{-6} \mathrm{M}$ t-RA or medium alone, electrophoresed on an agarose gel, and examined for evidence of DNA laddering. No evidence of DNA fragmentation was observed in control or t-RA-treated cells (data not shown), demonstrating no detectable levels of programmed cell death. Nonadherent cells were found to be $<10^{3}$ per $10-\mathrm{cm}$ plate after $5 \mathrm{~d}$ of treatment with or without t-RA, suggesting that the media did not contain significant numbers of apoptotic cells.

Effect of $R A R$ - and $R X R$-selective retinoids on normal $H B E$ cell growth. We examined the role of RAR- and RXRdependent signaling pathways in the growth inhibition induced by t-RA treatment. Normal HBE cells were treated for $5 \mathrm{~d}$ with different dosages of the RAR-selective retinoid TTNPB, the RXR-selective retinoid SR11235, or t-RA, and cell density was measured by performing a Sulforhodamine B colorimetric assay. Previously, we have demonstrated RAR-agonistic ef- 

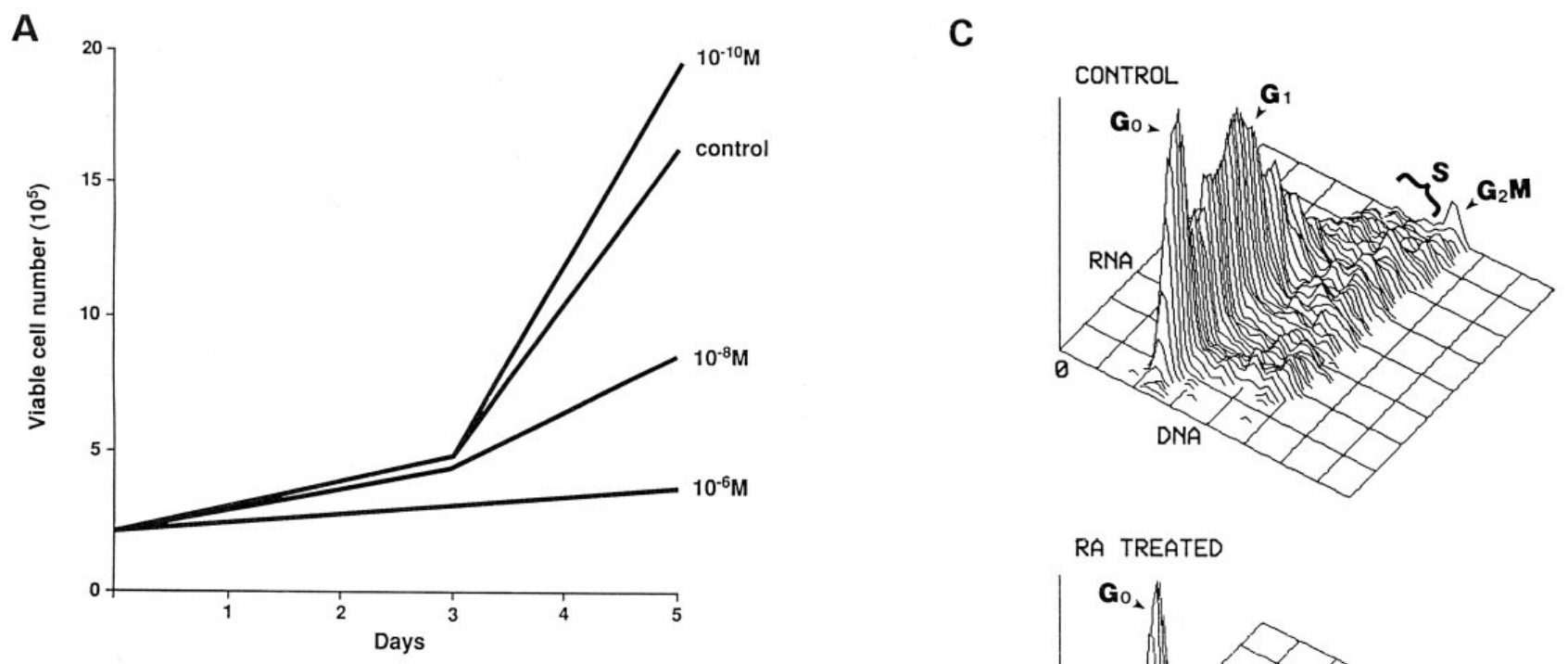

RA TREATED

B

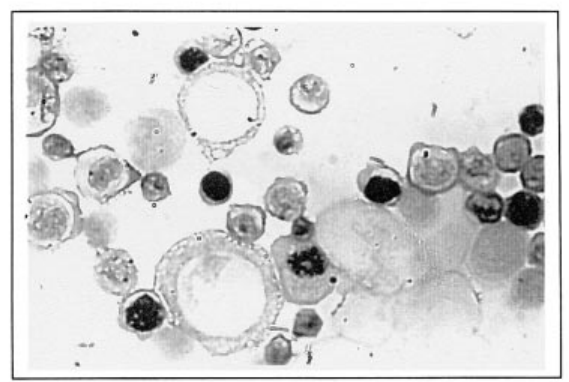

\begin{tabular}{|c|c|c|c|}
\hline \multicolumn{4}{|c|}{ BrdU Incorporation } \\
\hline Biopsy & control & $\underline{\mathrm{t}-\mathrm{RA}}$ & Inhibition \\
\hline 1 & $17 \%$ & $3 \%$ & $85 \%$ \\
\hline 2 & $18 \%$ & $6 \%$ & $67 \%$ \\
\hline 3 & $28 \%$ & $18 \%$ & $34 \%$ \\
\hline
\end{tabular}

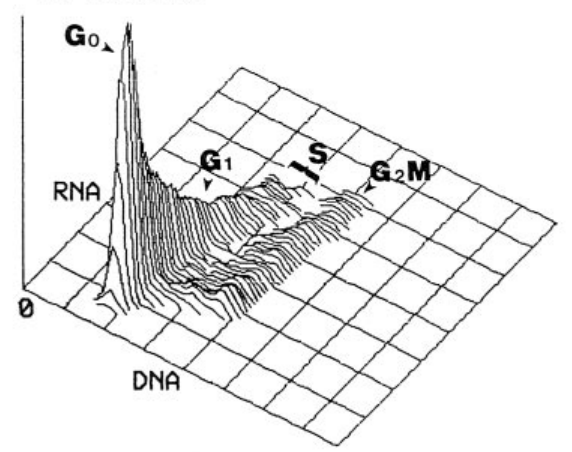

\begin{tabular}{|c|c|c|}
\hline$\%$ Gated Cells & Control & t-RA \\
\hline G0 & 6 & 38 \\
\hline G1 & 41 & 25 \\
\hline S & 37 & 23 \\
\hline G2/M & 16 & 14 \\
\hline
\end{tabular}

Figure 1. Cell counts were performed $(A)$ after normal HBE cells were seeded at a density of $2 \times 10^{5}$ cells per 10 -cm plate, treated with the indicated dosages of t-RA or medium alone for 3 or $5 \mathrm{~d}$, trypsinized, and stained with trypan blue. The total numbers of viable cells were counted by using a hemocytometer. BrdU incorporation was examined $(B)$ after normal HBE cells were grown from three separate bronchial biopsies, seeded at a density of $10^{5}$ cells per $10-\mathrm{cm}$ plate, and treated for $5 \mathrm{~d}$ with $10^{-6} \mathrm{M} \mathrm{t}-\mathrm{RA}$ or media alone. Before trypsinization, the cells were treated with $10 \mathrm{mg} / \mathrm{ml} \mathrm{BrdU}$ for $30 \mathrm{~min}$. Cytospin preparations were made, and BrdU incorporation was detected with an anti-BrdU monoclonal antibody followed by staining with the Vectastain ABC Elite kit and diaminobenzidine. Cells incorporating BrdU demonstrate staining within nuclei. The percentages of BrdU-positive cells were determined among 500 randomly counted cells. Flow cytometric analysis was performed $(C)$ after normal HBE cells were seeded at a density of $10^{5}$ cells per $10-\mathrm{cm}$ plate, treated with $10^{-6} \mathrm{M} \mathrm{t}$-RA or media alone for $5 \mathrm{~d}$, trypsinized, and stained with acridine orange. Flow cytometry was performed on $10^{6}$ cells to examine the percentages in each phase of the cell cycle. The peaks representing $\mathrm{G}_{0}, \mathrm{G}_{1}, \mathrm{~S}$, and $\mathrm{G}_{2} / \mathrm{M}$ are indicated. The percentages of gated control and t-RA-treated normal HBE cells in each phase of the cell cycle were tabulated from the flow cytometric analysis.

fects with TTNPB but not SR11235 treatment in normal HBE cells (40). TTNPB reduced cell density in a dose-dependent manner, whereas SR11235 had minimal effects on cell density (Fig. 2). A growth inhibitory effect was detectable with $10^{-10} \mathrm{M}$ TTNPB, demonstrating that TTNPB was more potent than t-RA in inhibiting normal HBE cell growth.

Role of E2F in retinoid signaling. We investigated the mechanisms by which t-RA induced an accumulation of normal $\mathrm{HBE}$ cells in the $\mathrm{G}_{0}$ phase. The best characterized regulator of $\mathrm{G}_{0}$ entry is the E2F family member E2F-4. With entry into $\mathrm{G}_{0}$,
E2F-4 becomes a transcriptional suppressor of key growth regulatory genes (41-43). Transient transfection assays were performed using reporter plasmids that have a portion of the E2F-1 gene promoter, which contains a variety of response elements including two E2F-binding sites (50). The E2F-binding sites in these reporter plasmids are either intact (pGL2-AN) or mutated so that E2F can not bind (pGL2-AN $\Delta \mathrm{A}+\mathrm{B})(50)$. E2F-1 gene promoter activity was examined in the absence of t-RA $(\mathrm{t}=0)$ and during sequential 24-h time periods $(0-24,24-48$, and $48-72 \mathrm{~h}$ ) of $10^{-6} \mathrm{M}$ t-RA treatment (Fig. $3 \mathrm{~A}$ ). Comparing 


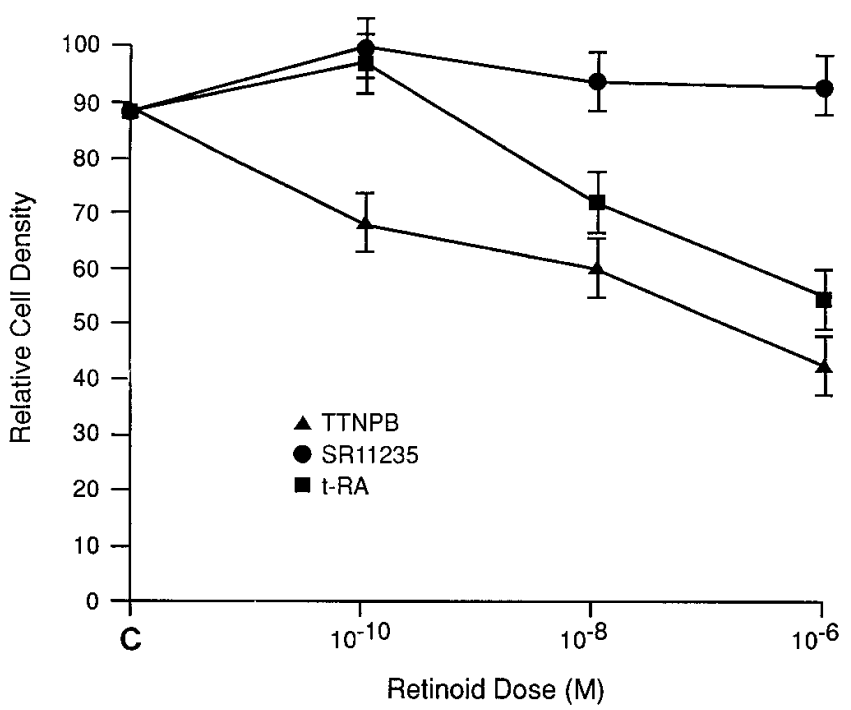

Figure 2. Normal HBE cells were seeded at a density of $3 \times 10^{3}$ cells per well on a 24-well plate, treated with the indicated dosages of retinoids for $5 \mathrm{~d}$, and relative cell densities were determined by staining the cells with the Sulforhodamine B Colorimetric Assay and measuring the absorption at a wavelength of $490 \mathrm{~nm}$. Results represent the means and SD of values obtained from five identical wells.

untreated and t-RA-treated cells transfected with pGL2-AN (A1B, luciferase activity increased 2.0- and 2.8-fold at 48 and $72 \mathrm{~h}$, respectively, of t-RA treatment, demonstrating that t-RA activated the E2F-1 gene promoter containing mutated E2Fbinding sites. In contrast, luciferase activity in cells transfected with pGL2-AN increased only 1.1- and 1.9-fold at 48 and $72 \mathrm{~h}$, respectively, suggesting that the E2F-binding sites inhibited t-RA-induced activation of the E2F-1 promoter.

One interpretation of this finding is that, in the presence of t-RA, the E2F binding sites in the E2F-1 gene promoter are negative regulatory elements and that E2F functions as a transcriptional suppressor. To further investigate this possibility, we performed Northern analysis of B-myb, cyclin A, and cyclin E, which contain E2F-binding sites in their promoter regions that regulate the expression of these genes (52). After $3 \mathrm{~d}$ of treatment with $10^{-6} \mathrm{M}$ t-RA or medium alone, expression of these E2F target genes decreased in the presence of t-RA (Fig. $3 B$ ), supporting the hypothesis that t-RA converted E2F into a transcriptional suppressor.

Potential mechanisms by which t-RA altered E2F function were examined. Upon entry into $\mathrm{G}_{0}, \mathrm{E} 2 \mathrm{~F}-4$ has been shown to accumulate in the nucleus, associate with p107 or p130, and bind to DNA on E2F-binding sites $(42,53,54)$. We investigated whether these changes take place in t-RA-treated normal HBE cells. Band shift analysis revealed two distinct nuclear complexes bound to the E2F-binding sites (E2FA and B) within the E2F-1 gene promoter, and their binding activities were competed with excess consensus, but not unrelated, cold oligonucleotide (Fig. $4 A$ ), confirming the presence of E2Fbinding activity in normal HBE cells. Band super shifts were performed with the pGL2-AN and pGL2-AN $\Delta \mathrm{A}+\mathrm{B}$ oligonucleotides using nuclear proteins prepared from cells treated for $3 \mathrm{~d}$ with t-RA in the presence of monoclonal antibodies to RAR- $\alpha$ or RXR- $\alpha$. The presence of antibodies to RAR- $\alpha$ or
A
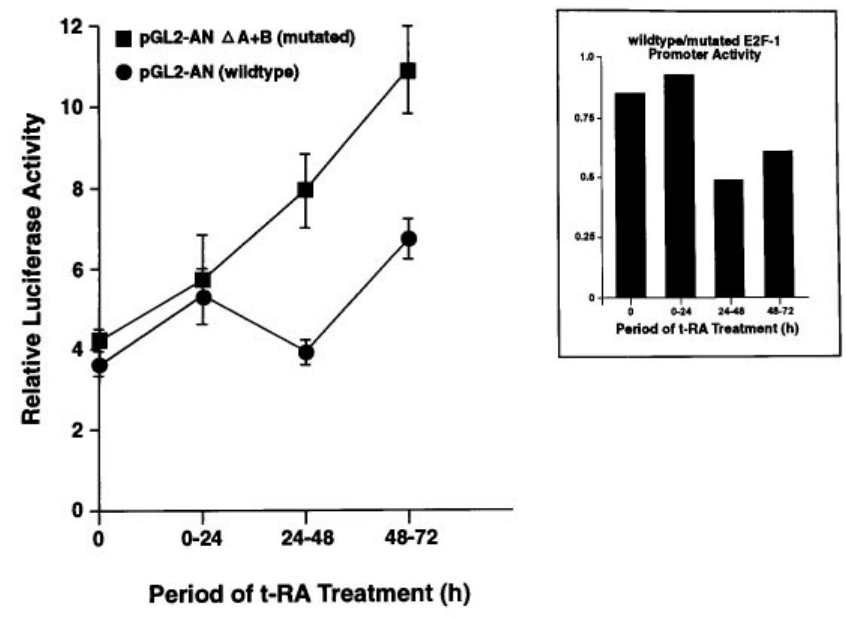

B
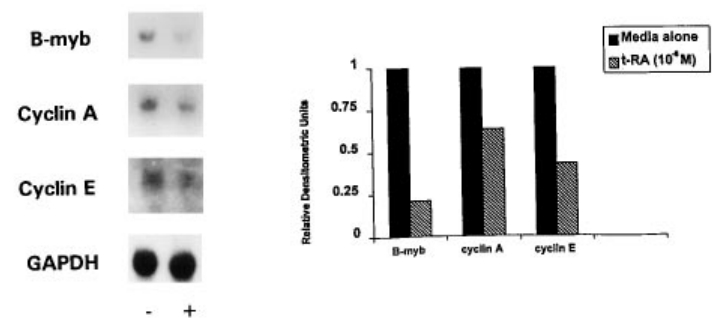

Figure 3. Transient transfection analysis $(A)$ was performed on normal HBE cells after seeding at a density of $10^{5}$ cells per well on a 6 -well plate. The cells were treated with media alone $(t=0)$ or with $10^{-6} \mathrm{M} \mathrm{t}$-RA beginning 72, 96, and $120 \mathrm{~h}$ after seeding. Transient transfections with pGL2-AN or pGL2-AN $\Delta \mathrm{A}+\mathrm{B}$ were performed at the $120 \mathrm{~h}$ time point. The cells were subjected to luciferase assays $24 \mathrm{~h}$ later (144 $\mathrm{h}$ time point). Each result represents a 24 -h time period $(0-24,24-48$, and 48-72 h) of t-RA treatment and is the mean and SD of luciferase values from five identical wells. Relative activity of the two reporter plasmids (wild type/mutant E2F) is illustrated for each time period, demonstrating the suppressive effect of the E2F sites on reporter plasmid activity from 24-72 h of t-RA treatment. Northern analysis $(B)$ of the indicated E2F target genes was performed on total cellular RNA (30 $\mu \mathrm{g}$ per lane) prepared from normal HBE cells that were treated with media alone (-) or $10^{-6} \mathrm{M} \mathrm{t}-\mathrm{RA}(+)$ for $3 \mathrm{~d}$. The membrane was hybridized sequentially to cDNAs of the indicated genes, including glyceraldehyde-3-phosphate dehydrogenase to examine relative amounts of RNA loaded per lane. Densitometric analysis was performed on the autoradiographs. The density of bands representing samples from t-RA-treated cells was calculated relative to that of untreated cells, which was set at 1 , following standardization for RNA loading based on the relative density of glyceraldehyde3-phosphate dehydrogenase bands.

RXR- $\alpha$ did not alter the mobility of bands associated with these oligonucleotides (data not shown), suggesting that retinoid receptors did not directly or indirectly bind to this promoter fragment. Western blotting of nuclear proteins from untreated cells revealed detectable E2F-4, p107, and p130, and t-RA treatment increased the levels of nuclear E2F-4, p107, and p130 (Fig. 4 B). Co-immunoprecipitation studies demon- 
A

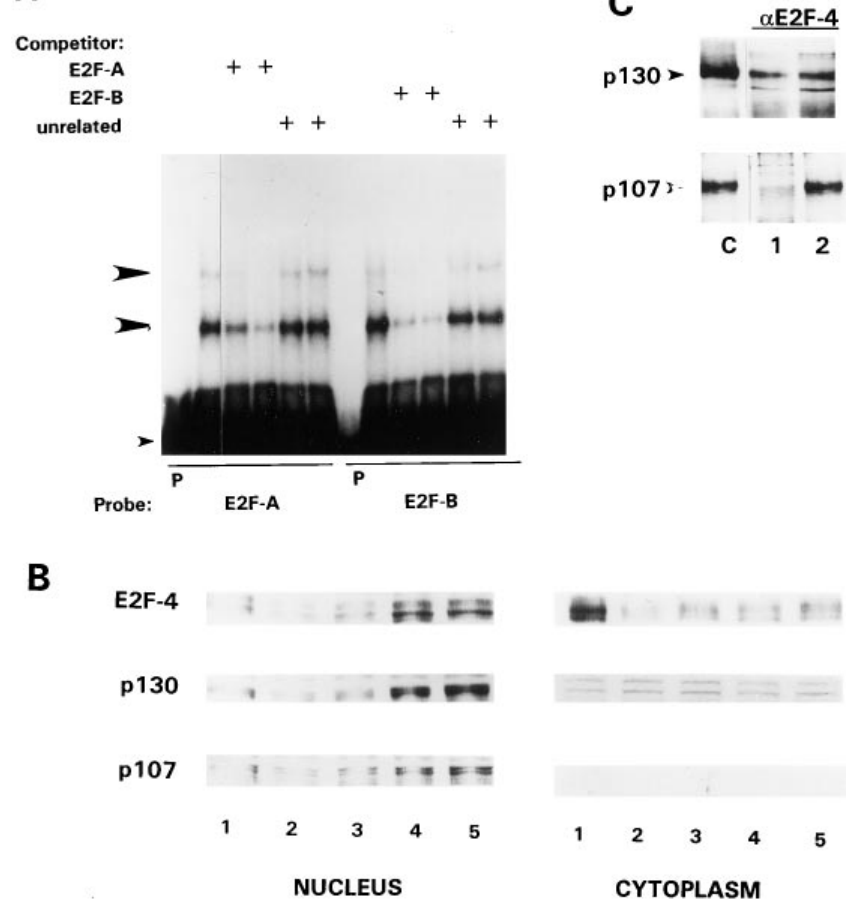

Figure 4. Band shift analysis $(A)$ was performed on nuclear lysates $(10 \mu \mathrm{g}$ per lane) prepared from normal HBE cells. As probes, oligomers containing portions of the E2F-1 gene promoter were prepared including the E2FA-binding site $(E 2 F-A)$ or the E2FB-binding site $(E 2 F-B)$. For competition experiments, nonradiolabeled E2F-A, E2F-B, or unrelated oligomers were added in 10- or 100-fold (adjacent lanes) excess before the addition of radiolabeled E2F-A or -B oligomers. Lanes containing radiolabeled E2FA or E2FB oligomers alone (no extract) are indicated $(P)$. Large arrows point to bands that represent two distinct E2F-binding complexes and small arrow points to free oligomers. Western analysis $(B)$ was performed on nuclear or cytoplasmic extracts (50 $\mu \mathrm{g}$ per lane) to examine expression of E2F-4, p107, and p130 in normal HBE cells treated with media alone (lane 1) or with $10^{-6} \mathrm{M}$ t-RA for 1 (lane 2), 2 (lane 3), 3 (lane 4), or 4 (lane 5) days. In $C$, whole cell extracts prepared from normal HBE cells treated with media alone (lane 1 ) or $10^{-6} \mathrm{M}$ t-RA for $3 \mathrm{~d}$ (lane 2) were immunoprecipitated $(300 \mu \mathrm{g}$ per sample) with a monoclonal antibody to E2F-4. The immunoprecipitated proteins were electrophoresed and Western blotted with monoclonal antibodies to p107 and p130. The positions of p107 and p130 were confirmed on the Western with whole cell extracts (lane $C$ ).

strated association of E2F-4 with p130 and, at lower levels, p107 in untreated cells, and t-RA treatment enhanced the association of E2F-4 with p130 and, to a greater extent, p107 (Fig. 4 C). These findings support a role for the E2F-4:p107 complex in retinoid signaling and in the conversion of E2F into a transcriptional suppressor.

\section{Discussion}

In this study, we investigated the effect of t-RA on the growth of normal HBE cells. We found that t-RA induced a proliferative arrest of normal HBE cells, which accumulated in the $\mathrm{G}_{0}$ phase with no evidence of programmed cell death. Treatment with RAR- and RXR-selective retinoids suggested that this growth inhibition was mediated through RAR-, but not RXRdependent signaling pathways. In addition, t-RA converted E2F into a transcriptional suppressor and enhanced the association of E2F-4 with p107. These findings point to RAR- and E2F-dependent pathways as potential mediators of retinoidinduced growth arrest and has implications for the use of retinoids in clinical trials on the prevention of lung cancer.

Investigating the role of specific classes of retinoid nuclear receptors, we found that a RAR-selective retinoid inhibited the growth of normal HBE cells. This corroborates findings in immortalized $\mathrm{HBE}$ and rat tracheobronchial epithelial cells $(55,56)$. In breast cancer cells, t-RA-induced growth inhibition can be mediated by RAR- $\alpha,-\beta$, or $-\chi-$ dependent signaling pathways $(57,58)$. In the immortalized rat tracheobronchial epithelial cell line SPOC-1, RAR- $\alpha$-dependent signaling pathways are reported to be the predominate mechanism of retinoid-induced growth suppression (56). In contrast to the RARselective retinoid TTNPB, the RXR-selective retinoid SR11235 did not inhibit the growth of normal HBE cells. Similarly, in other cell types, RAR- and RXR-selective retinoids differ in their effects on growth (33-35). Previous studies have revealed a basis for their divergent biologic effects. RAR-selective retinoids transcriptionally activate RXR:RAR heterodimers, whereas RXR-selective retinoids activate heterodimers of RXRs with orphan receptors in which RXR is a ligand-binding partner (17-27). Further, RAR and RXR signaling pathways regulate the expression of distinct target genes and have opposing effects on the same target gene $(59,60)$. In contrast to their divergent effects on growth, both RAR- and RXR-selective retinoids inhibit the squamous differentiation of $\mathrm{HBE}$ cells (40). This appears to be at least partly the result of the suppressive effects of these retinoids on the AP-1 transcription factor, which binds the promoters and activates the expression of a variety of genes required for the induction of HBE squamous differentiation (40).

The signaling events activated by RXR:RAR heterodimers that inhibit normal $\mathrm{HBE}$ cell growth are not known. Because t-RA caused normal HBE cells to accumulate in the $\mathrm{G}_{0}$ phase, we investigated whether t-RA activates mechanisms known to control entry into $G_{0}$. Upon entry of cells into quiescence due to growth factor deprivation, senescence, or TGF- $\beta$ treatment, E2F becomes a transcriptional suppressor $(41-43,54,61)$. Among the E2F family members, E2F-4 is most specifically involved in this cell cycle transition $(42,53,54)$. E2F-4 levels increase in the nucleus (52), and E2F-4 associates with RB family members, converting E2F into a transcriptional suppressor. Among the RB family members, p130 specifically associates with E2F in serum-starved REF-52 fibroblasts, whereas $\mathrm{pRB}$ and p107 associate with E2F-4 in TGF- $\beta$-treated HaCaT colon cancer cells $(42,54)$. Similarly, we found that t-RA converted E2F into a transcriptional suppressor, inhibiting the expression of E2F target genes and converting E2F-binding sites in the E2F-1 gene promoter into negative regulatory elements. Further, t-RA increased nuclear levels of E2F-4, p107, and p130 and enhanced the association of E2F-4 with p130 and, to a greater extent, p107. Arguing against the involvement of pRB in t-RA actions, Western analysis demonstrated that t-RA did not detectably change the gel mobility of $\mathrm{pRB}$, which was predominantly hyperphosphorylated in normal HBE cells (data not shown). These results support a role for E2F in retinoid signaling, and further investigations into the role of E2F-4: p107 complexes in t-RA-induced growth arrest are indicated. 
The findings presented here suggest that the growth of normal HBE cells can be inhibited by treatment with synthetic retinoids that selectively activate RAR-dependent signaling pathways or by treatment with agents that activate the formation of E2F-4:p107 complexes. These results have implications in the design of future lung cancer prevention trials for two reasons. First, synthetic retinoids that function as agonists or antagonists of specific retinoid receptors are entering clinical trials, allowing treatment to be directed toward specific retinoid signaling pathways. Second, as part of ongoing clinical trials at these institutions and elsewhere, biologic parameters are being tested for their usefulness as endpoints to predict the efficacy of agents in lung cancer prevention. These parameters are based on the biologic effects of retinoids in normal and immortalized HBE cells, including proliferative arrest (9), induction of mucous differentiation (8), reversal of squamous differentiation (3-7), and apoptosis (56). Further work must be performed in order to define the molecular mechanisms responsible for these biologic effects in HBE cells and which of these diverse actions are important in the preventive effects of retinoid treatment in individuals at increased risk for the development of lung cancer.

\section{Acknowledgments}

This work was supported by National Institutes of Health grants R29 CA67353, PO1 CA16672, PO1 CA55164, and P50CA70907, and by grants from the University Cancer Foundation and the Physicians Referral Service, The University of Texas M.D. Anderson Cancer Center.

\section{References}

1. Wolbach, S.B, and P.T. Howe. 1925. Tissue changes following deprivation of fat soluble A vitamin. J. Exp. Med. 42:754-778.

2. Chopra, D.P. 1982. Squamous changes in organ cultures of vitamin A-deficient hamster trachea: cytokinetic and ultrastructural alterations. J. Natl. Cancer Inst. 69:895-901.

3. Jetten, A.M., J.I. Rearick, and H.L. Smits. 1986. Regulation of differentiation of airway epithelial cells by retinoids. Biochem. Soc. Trans. 14:930-933.

4. Jetten, A.M., J.E. Shirley, and G. Stoner. 1986. Regulation of proliferation and differentiation of respiratory tract epithelial cells by TGF-beta. Exp. Cell Res. 167:539-549.

5. Masui, T., L.M. Wakefield, J.F. Lechner, M.A. LaVeck, M.B. Sporn, and C.C. Harris. 1986. Type beta transforming growth factor is the primary differentiation-inducing serum factor for normal bronchial epithelial cells. Proc. Natl. Acad. Sci. USA. 83:2438-2442.

6. Willey, J.C., C.E. Moser, Jr., J.F. Lechner, and C.C. Harris. 1984. Differential effects of 12-0-tetradecanoylphorbol-13-acetate on cultured normal and neoplastic human bronchial epithelial cells. Cancer Res. 44:5124-5126.

7. Saunders, N.A., and A.M. Jetten. 1994. Control of growth regulatory and differentiation-specific genes in human epidermal keratinocytes by interferongamma. Antagonism by retinoic acid and transforming growth factor-beta 1.J. Biol. Chem. 269:2016-2022.

8. Inayama, Y., G.E.R. Hook, A.R. Brody, G.S. Cameron, A.M. Jetten, L.B. Gilmore, T. Gray, and P. Nettesheim. 1988. The differentiation potential of tracheal basal cells. Lab. Invest. 58:706-717.

9. Miller, L.A., L.Z. Cheng, and R. Wu. 1993. Inhibition of epidermal growth factor-like growth factor secretion in tracheobronchial epithelial cells by vitamin A. Cancer Res. 53:2527-2533.

10. Pastorino, U., M. Infante, M. Maioli, G. Chesa, M. Buyse, P. Firket, N. Rosmentz, M., Clerici, E. Soresi, M. Valente, P.A. Belloni, and G. Ravasi. 1993. Adjuvant treatment of stage I lung cancer with high dose vitamin A. J. Clin. Oncol. 11:1216-1222.

11. Giguere, V., E.S. Ong, P. Segui, and R.M. Evans. 1987. Identification of a receptor for the morphogen retinoic acid. Nature. 330:624-629.

12. Petkovich, M., N.J. Brand, A. Krust, and P. Chambon. 1987. A human retinoic acid receptor which belongs to the family of nuclear receptors. Nature. 330:444-450.

13. Brand, N., M. Petkovich, A. Krust, P. Chambon, H. Marchio, G. de The, A. Marchio, P. Thiollais, and A. Dejean. 1988. Identification of a second retin- oic acid receptor. Nature. 332:851-853

14. Krust, A., P.H. Kastner, M. Petkovich, A. Zelent, and P. Chambon 1989. A third human retinoic acid receptor, HRAR-gamma. Proc. Natl. Acad. Sci. USA. 86:5310-5314.

15. Mangelsdorf, D., E.S. Ong., J.A. Dyck, and R.M. Evans. 1990. Nuclear receptor that identifies a novel retinoic acid response pathway. Nature. 345: 224-229.

16. Mangelsdorf, D., U. Borgmeyer, R.A. Heyman, J.Y. Zhou, E.S. Ong, A.E. Oro, A. Kakizuka, and R.M. Evans. 1992. Characterization of three RXR genes that mediate the effects of 9-cis retinoic acid. Genes Dev. 6:329-344.

17. Leid, M., P. Kastner, R. Lyons, H. Nakshatri, M. Saunders, T. Zacharewski, J.-Y. Chen, A. Staub, J.M. Garnier, S. Mader, and P. Chambon. 1992 Purification, cloning, and RXR identity of the HeLa cell factor with which RAR or TR heterodimerizes to bind target sequences efficiently. Cell. 68:377395 .

18. Zhang, X., B. Hoffmann, P.B.V. Tran, G. Graupner, and M. Pfahl. 1992. Retinoid X receptor is an auxiliary protein for thyroid hormone and retinoic acid receptors. Nature. 355:441-446.

19. Marks, S.M., P.L. Hallenbeck, T. Nagata, J.H. Segars, E. Appella, V.M. Nikodem, and K. Ozato. 1992. H-2RIIBP (RXR beta) heterodimerization provides a mechanism for combinatorial diversity in the regulation of retinoic acid and thyroid hormone responsive genes. EMBO (Eur. Mol. Biol. Organ.) J. 11: 1419-1435.

20. Bugge, T.H., J. Pohl, O. Lonnoy, and H.G. Stunnenberg. 1992. RXR alpha, a promiscuous partner of retinoic acid and thyroid hormone receptors. EMBO (Eur. Mol. Biol. Organ.) J. 11:1409-1418.

21. Yu, V.C., C. Delsert, B. Andersen, J.M. Holloway, O.V. Devary, A.M. Näär, S.Y. Kim, J.-M. Boutein, C.K. Glass, and M.G. Rosenfeld. 1991. RXR beta: a co-regulator that enhances binding of retinoic acid, thyroid hormone, and vitamin D receptors to their cognate response elements. Cell. 67:1251-1266.

22. Kliewer, S.A., K. Umesono, D.J. Mangelsdorf, and R.M. Evans. 1992. Retinoid X receptor interacts with nuclear receptors in retinoic acid, thyroid hormone, and vitamin D3 signaling. Nature. 355:446-449.

23. Forman, B.M., E. Goode, J. Chen, A.E. Oro, D.J. Bradley, T. Perimann, D.J. Noonan, L.T. Burka, T. McMorris, W.W. Lamph, R.M. Evans, and C. Weinberger. 1995. Identification of a nuclear receptor that is activated by farnesol metabolites. Cell. 81:687-693.

24. Kliewer, S.A., K. Umesono, D.J. Noonan, R.A. Heyman, and R.M. Evans. 1992. Convergence of 9-cis retinoic acid and peroxisome proliferator signalling pathways through heterodimer formation of their receptors. Nature. 358:771-774.

25. Willy, P.J., K. Umesono, E.S. Ong, R.M. Evans, R.A. Heyman, and D.J. Mangelsdorf. 1995. LXR, a nuclear receptor that defines a distinct retinoid response pathway. Genes Dev. 9:1033-1045.

26. Law, S.W., O.M. Conneely, F.J. DeMayo, and B.W. O'Malley. 1992. Identification of a new brain-specific transcription factor. Mol. Endocrinol. 6: 2129-2135.

27. Perlmann, T., and L. Jansson. 1995. A novel pathway for vitamin A signaling mediated by RXR heterodimerization with NGFI-B and NURR-1. Genes Dev. 9:769-782.

28. Heyman, R.A., D.J. Mangelsdorf, J.A. Dyck, R.B. Stein, G. Eichele, R.M. Evans, and C. Thaller. 1992. 9-cis retinoic acid is a high affinity ligand for the retinoid X receptor. Cell. 68:397-406.

29. Levin, A.A., L.J. Sturzenbecker, S. Kazmer, T. Bosakowski, C. Huselton, G. Allenby, J. Speck, C. Kratzeinsen, M. Rosenberger, A. Lovey, and J.F. Grippo. 1992. 9-cis retinoic acid stereoisomer binds and activates the nuclear receptor RXR-alpha. Nature. 355:359-361.

30. Urbach, J., and R.R. Rando. 1994. Thiol dependent isomerization of alltrans retinoic acid to 9-cis retinoic acid. Biochem. J. 299:459-465.

31. Lehmann, J.M., M.I. Dawson, P.D. Hobbs, M. Husmann, and M. Pfahl. 1991. Identification of retinoids with nuclear receptor subtype-selective activities. Cancer Res. 51:4804-4809.

32. Lehmann, J.M., L. Jong, A. Fanjul, J.F. Cameron, X.P. Lu, P. Haefner, M.I. Dawson, and M. Pfahl. 1992. Retinoids selective for retinoid X receptor response pathways. Science. 258:1944-1946.

33. Agarwal, C., R.A.S. Chandraratna, M. Teng, S. Nagpal, E.A. Rorke, and R.L. Eckert. 1996. Differential regulation of human ectocervical epithelial cell line proliferation and differentiation by retinoid $\mathrm{X}$ receptor- and retinoic acid receptor-specific retinoids. Cell Growth Differ. 7:521-530.

34. Mills, K.J., T.M. Vollberg, C. Nervi, J.F. Grippo, M.I. Dawson, and A.M. Jetten. 1996. Regulation of retinoid-induced differentiation in embryonal carcinoma PCC4.aza1R cells: effects of retinoid-receptor selective ligands. Cell Growth Differ. 7:327-337.

35. Nagy, L., V.A. Thomázy, G.L. Shipley, L. Fésüs, W. Lamph, R.A. Heyman, R.A.S. Chandraratna, and P.J.A. Davies. 1995. Activation of retinoid X receptors induces apoptosis in HL-60 cell lines. Mol. Cell. Biol. 15:3540-3551.

36. Gazit, D., R. Ebner, A.J. Kahn, and R. Derynck. 1993. Modulation of expression and cell surface binding of members of the transforming growth factor superfamily during retinoic acid-induced osteoblastic differentiation of multipotential mesenchymal cells. Mol. Endocrinol. 7:189-198.

37. Glick, A.B., K.C. Flanders, D. Danielpour, S.H. Yuspa, and M.B. Sporn. 1989. Retinoic acid induces transforming growth factor-beta2 in cultured kera- 
tinocytes and mouse epidermis. Cell Regul. 1:87-97.

38. Andreatta-Van Leyen, S., J.R. Hembree, and R.L. Eckert. 1994. Regulation of insulin-like growth factor 1 binding protein 3 levels by epidermal growth factor and retinoic acid in cervical epithelial cells. J. Cell. Physiol. 160: 265-274

39. Sheikh, M.S., A.-M. Shao, A. Hussain, D.R. Clemmons, J.-C. Chen, C.T. Roberts, Jr., D. LeRoith, and J.A. Fontana. 1993. Regulation of insulin-like growth factor binding protein-1, $-2,-3,-4,-5$, and -6 : estrogen receptor-negative human breast carcinoma cells. J. Cell. Physiol. 155:556-567.

40. Lee, H.-Y., M.I. Dawson, G.L. Walsh, J.C. Nesbitt, R.L. Eckert, E. Fuchs, W.K. Hong, R. Lotan, and J.M. Kurie. 1996. Retinoic acid receptor- and retinoid $\mathrm{X}$ receptor-selective retinoids activate signaling pathways that converge on AP-1 and inhibit squamous differentiation in human bronchial epithelial cells. Cell Growth Differ. 7:997-1004.

41. Weintraub, S.J., K.N.B. Chow, R.X. Luo, S.H. Zhang, S. He, and D.C. Dean. 1995. Mechanism of active transcriptional repression by the retinoblastoma protein. Nature. 375:812-815.

42. Smith, E.J., G. Leone, J. DeGregori, L. Jakoi, and J.R. Nevins. 1996. The accumulation of an E2F-p130 transcriptional repressor distinguishes a $\mathrm{G}_{0}$ cell state from a $\mathrm{G}_{1}$ cell state. Mol. Cell. Biol. 16:6965-6976.

43. Weintraub, S.J., C.J. Prater, and D.C. Dean. 1992. Retinoblastoma protein switches the E2F site from positive to negative element. Nature. 358:259261.

44. Kim, Y.-H., D.F. Dohi, G.R. Han, C.-P. Zou, N. Oridate, G.L. Walsh, J.C. Nesbitt, X.-C. Xu, W.K. Hong, R. Lotan, and J.M. Kurie. 1995. Retinoid refractoriness occurs during lung carcinogenesis despite functional retinoid receptors. Cancer Res. 55:5603-5610.

45. Boehm, M.F., L. Zhang, B.A. Badea, S.K. White, D.E. Mais, E. Berger, C.M. Suto, M.E. Goldman, and R.A. Heyman. 1994. Synthesis and structureactivity relationships of novel retinoid X receptor-selective retinoids. J. Med. Chem. 37:2930-2941.

46. Dawson, M.I., L. Jong, P.D. Hobbs, J.F. Cameron, W.-R. Chao, M. Pfahl, M.-O. Lee, B. Shroot, and M. Pfahl. 1995. Conformational effects on retinoid receptor selectivity. II. Effects of retinoid bridging group on retinoid $\mathrm{X}$ receptor activity and selectivity. J. Med. Chem. 38:3368-3383.

47. Gavrieli, Y., M. Sherman, and S.A. Ben-Sasson. 1992. Identification of programmed cell death in situ via specific labeling of nuclear DNA fragmentation. J. Cell Biol. 119:493-501.

48. Coltera, M.D., and A.M. Gown. 1991. PCNA/cyclin expression and BrdU uptake define different subpopulations in different cell lines. J. Histochem. Cytochem. 39:23-30.

49. Darzynkiewicz, Z., and J. Kapuscinski. 1990. Acridine orange: a versatile probe of nucleic acids and other cell constituents. In Flow Cytometry and Sorting (2nd ed.). Wiley-Liss, Inc., New York. 291-314.

50. Neuman, E., E.K. Flemington, W.R. Sellers, and W.G. Kaelin. 1994.
Transcription of the E2F-1 gene is rendered cell cycle dependent by E2F DNAbinding sites within its promoter. Mol. Cell. Biol. 14: 6607-6615.

51. Zou, A., M.G. Elgort, and E.A. Allegretto. 1997. Retinoid X receptor (RXR) ligands activate the human 25-hydroxyvitamin D3-24-hydroxylase promoter via RXR heterodimer binding to two vitamin D-responsive elements and elicit additive effects with 1,25-dihydroxyvitamin D3. J. Biol. Chem. 272: 1902719034

52. Leone, G., J. DeGregori, R. Sears, L. Jakoi, and J.R. Nevins. 1997. Myc and ras collaborate in inducing accumulation of active cyclin E/cdk2 and E2F. Nature. 387:422-426.

53. Lindeman, G.J., S. Gaubatz, D.M. Livingston, and D. Ginsberg. 1997. The subcellular localization of E2F-4 is cell cycle-dependent. Proc. Natl. Acad. Sci. USA. 94:5095-5100.

54. Li, J.-M., P.P. Hu, X. Shen, Y. Yu, and X.-F. Wang. 1997. E2F4-RB and E2F4-p107 complexes suppress gene expression by transforming growth factor $\beta$ through E2F sites. Proc. Natl. Acad. Sci. USA. 94:4948-4953.

55. Ahn, M.J., J. Langenfeld, M.M. Moasser, V. Rusch, and E. Dmitrovsky. 1995. Growth suppression of transformed human bronchial epithelial cells by all-trans retinoic acid occurs through specific retinoid receptors. Oncogene. 11: 2357-2364.

56. Zhang, L.-X., K.J. Mills, M.I. Dawson, S.J. Collins, and A.M. Jetten. 1994. Evidence for the involvement of retinoic acid receptor-alpha-dependent signaling pathway in the induction of tissue transglutaminase and apoptosis by retinoids. J. Biol. Chem. 270:6022-6029.

57. Dawson, M.I., W. Chao, P. Pine, L. Jong, P.D. Hobbs, C.K. Rudd, T.C. Quick, R.M. Niles, X. Zhang, A. Lombardo, et al. 1995. Correlation of retinoid binding affinity to retinoic acid receptor alpha with retinoid inhibition of growth of estrogen receptor-positive MCF-7 mammary carcinoma cells. Cancer Res. 55:4446-4451.

58. Seewaldt, V.L., B.S. Johnson, M.B. Parker, S.J. Collins, and K. Swisshelm. 1995. Expression of retinoic acid receptor-beta mediates retinoic acidinduced growth arrest and apoptosis in breast cancer cells. Cell Growth Differ. 6:1077-1088.

59. Hembree, J.R., C. Agarwal, R.L. Beard, R.A.S. Chandraratna, and R.L. Eckert. 1996. Retinoid X receptor-specific retinoids inhibit the ability of retin oic acid receptor-specific retinoids to increase the level of insulin-like growth factor binding protein-3 in human ectocervical epithelial cells. Cancer Res. 56: 1794-1799.

60. Vu-dac, N., K. Schoonjans, V. Kosykh, J. Dallongeville, R.A. Heyman, B. Steals, and J. Auwerx. 1996. Retinoids increase human apolipoprotein A-II expression through activation of the retinoid $\mathrm{X}$ receptor but not the retinoic acid receptor. Mol. Cell. Biol. 16:3350-3360.

61. Afshari, C.A., M.A. Nichols, Y. Xiiong, and M. Mudryj. 1996. A role for a p21-E2F interaction during senescence arrest of normal human fibroblasts. Cell Growth Differ. 7:979-988. 